\title{
Lexical and Phonological Differences in Javanese in Probolinggo, Surabaya, and Ngawi, Indonesia
}

\author{
Erlin Kartikasari \\ Universitas Wijaya Kusuma Surabaya, Indonesia \\ Diyas Age Larasati \\ Universitas Wijaya Kusuma Surabaya, Indonesia \\ Wakit A. Rais \\ Universitas Sebelas Maret, Solo, Indonesia \\ Warto \\ Universitas Sebelas Maret, Solo, Indonesia
}

\begin{abstract}
This study aims to reveal part of language components named lexical and phonological differences in Javanese in East Java, Indonesia. Data were collected from a sample of three regions which are Probolinggo, Surabaya, and Ngawi. Probolinggo was chosen because of its adjacency to Madura Island. Surabaya was chosen because of its strategic location not only the centre of government, but also as the Capital City of East Java Province. Meanwhile, Ngawi was chosen because of its location in the west-end of East Java and directly adjacent to Central Java Province. This research is a quantitative research. The data were Javanese used by adults in East Java, especially in Probolinggo, Surabaya, and Ngawi. The research instrument used was Nothofer questionnaire which was modified by Kisyani to be 829 glossaries of words/phrases. The results of the study revealed that: 1) the most lexical of Javanese was in the western and eastern parts of East Java thus the least was in the central government of East Java Province, Surabaya, 2) lexical differences in Javanese in Probolinggo, Surabaya, and Ngawi result in one dialect and two sub dialects, and 3) phonological differences in Javanese in Probolinggo, Surabaya, and Ngawi produced three utterances.
\end{abstract}

Index Terms - lexical, phonological, Javanese, dialects, sub dialects, utterance

\section{INTRODUCTION}

Language is predetermined as a significant aspect that can change human life. Every human being has a close relationship of language. A philosopher expressed thoughts and the results of his reflections by using language. Therefore, without language, human would not understand the philosophical thoughts. Language and philosophy are like two lovebirds that cannot be separated or two sides of a coin that complement each other. There is a Javanese proverb that reads “ajining dhiri dumunung ing lathi, ajining raga dumunung ing busana, ”. It implies that the personal value of a human is determined by language, thus the value of a human appearance is determined by clothing. The language spoken by humans must contain goodness and politeness because of it reflects the high dignity of a human being and the high civilization of a nation. Thus, language reflects the quality of the individual in the life of society; nation and state (see Sasangka, 2011, Suhono, 1953, Poerwadarminta, 1953).

Based on dialectological review, research on lexical differences and phonological differences in Javanese language in Probolinggo, Surabaya, and Ngawi is reasonable. Javanese is one of the local languages in Indonesia. Among the local languages, Javanese is the language with the most speakers compared to other regional languages in Indonesia. The study of Javanese language in East Java is important to reveal the facts of differences in Javanese language in the eastern part of Java Island, which is directly adjacent to Madura and Bali Island which have other regional languages that is Madurese and Balinese (see Petyt, 1980, Ayatrohaedi, 1983, Chambers and Trudgill, 1990, Mahsun, 1995, Kisyani and Savitri, 2009).

East Java Province consists of three parts: the central government, i.e. Surabaya, and the suburb which consists of the east and west parts. The East is represented by Probolinggo and the western part is represented by Ngawi. Surabaya is a major port and a commercial trade centre of eastern Indonesia and now one of the largest cities in Southeast Asia, in which many domestics and foreign investors are investing to build companies, factories and malls. This caused a lot of urbanization of people from various regions to find work in the city. This mixture of people from various regions from within and outside the country in Surabaya City has caused variants of languages from various languages, including Madurese, Chinese, Arabic, English and other languages that can influence the existence of Javanese in Surabaya.

Ngawi is one of the regencies located on the west end of East Java Province, which is directly adjacent to Central Java Province. Central Java Province has two Javanese Palace or palaces which is still well-known in Indonesia. The 
two Palaces are Surakarta Hadiningrat Palace, located in Solo and Yogyakarta Hadiningrat Palace located in Yogyakarta. Both palaces are still very close with Javanese language and culture. The fact that Ngawi is close to the two palaces is expected to bring positive value of the existence of Javanese in Ngawi.

Probolinggo is a district located on the east end of East Java Province, which is directly adjacent to Madura and Bali Island, which have its own regional languages, i.e. Madurese and Balinese. The fact that East Java Province is close to the two islands is possible to influence the existence of Javanese language in Probolinggo.

Based on a sample of the three research locations, it can be questioned: how many existing lexical Javanese in Probolinggo, Surabaya, and Ngawi? What are the lexical and phonological differences of Javanese language in Probolinggo, Surabaya, and Ngawi? These questions are the consideration of the researchers to conduct a study related to Javanese language in East Java.

The study of Javanese language with dialectological studies is worthy of research and has its own appeal, proven by many researchers who studied language. There were several studies which have been done in the past: A Study of Dialectology on Javanese "Ngoko" in Banyuwangi, Surabaya, Magetan, and Solo by Erlin Kartikasari; KisyaniLaksono; Agusniar Dian Savitri; Diah Yovita Suryarini (2018) resulted on the largest number of Javanese "ngoko" lexical is found in Solo while the least were found in Surabaya. The lexical differences in Javanese "ngoko" in Banyuwangi, Surabaya, Magetan, and Solo resulted in one utterance, two dialects and four sub-dialects, (2)19 patterns of phonological differences in Javanese "ngoko" were found. Also, the phonological differences in Javanese "ngoko" in Banyuwangi, Surabaya, Magetan, and Solo resulted in four utterances.

The Realization of Intensifiers in Banyumas Dialect by Chusni Hadiati (2017) findings that speaker Banyumas dialect express their intensity by using several linguistic devices including lexical items and reduplication. General lexical items consist of banget and pisan. Specific lexical items include rea, regeng, leder, njilep, cirut, lecit, kecu, kethuwek.

The Relativity Strategy of Old Javanese by Ni Ketut Ratna Erawati (2017) the result is the Old Javanese could make the subject to be relative by inserting element of the relative sang and ikang. On the other hand, there was also an indirect relativity by marking of verbs and pen loping.

Another research outcome about the geography of the Javanese Coastal Dialect in Paciran Village, Lamongan Regency conducted by Apriyani Purwaningsih (2017) with the findings: (1) phonological isogloss file has five distribution patterns and lexical isogloss file has four patterns of distribution; (2) phonological variation is manifest from variations in allophones, sound addition, sound reduction, sound shifting, sound reduction in closed syllables, and sound substitution; (3) lexical variations caused by onomasiological, semasiological, and reduplication; (4) there are differences in speech and sub-dialect at the phonological level. At the lexical level, there is no difference. It included in the Proceedings of the International Conference on Art, Language, and Culture.

Variations of Javanese Dialect in the District of Ngawi: Dialectology Study by Ika Mamik Rahayu (2018) produced a conclusion of research using 250 lexicons in data acquisition; the list of questions in the form of this lexicon refers to the list of Swadesh questions. Out of 250 lexicons, 23 phonological variations and 47 lexical variations were obtained. In both variations, it was found that words/phrases experienced the process of apheresis and syncope. In addition, there are also cluster sounds and accompanying or nasalization sounds of several words/phrases. All variations that appear later are also presented in the form of dialect maps to further clarify the linguistic situation in the area of observation. The dialect variation that appears in the Ngawi Regency region is not a separate dialect, but rather a variant of Javanese. The Ngawi Regency dialect tends to refer to the Central Javanese dialect. In all observation areas, there were several references that appeared to refer to Indonesian.

Based on research on Javanese, it is necessary to conduct further investigation. This study specializes in the scope of Javanese languages in East Java. To find out the lexical differences and phonological differences in Javanese in East Java, it is necessary to identify Javanese languages in Probolinggo, Surabaya, and Ngawi.

\section{THEORY AND CONCEPT}

The term dialectology comes from the word dialect and the word logi. The word dialect comes from the Greek dialectos. The word dialectos is used to refer to the language conditions in Greek which show small differences in the language they use. However, this difference does not cause the speakers to feel that they have a different language (Meillet, 1967).

Meillet stated that the term dialect comes from Greek which is derived from the word dialectos. Dialectos which means shows differences in a language, however, the difference does not really affect the language used. Even though there are language differences, each speaker can still understand the language. Speakers and speakers can still communicate even though they use different dialects.

Kisyani (2004) stated that, in general, dialectology is the study of certain dialects or dialects of a language. in the broadest sense dialectological research seeks to describe differences in linguistic patterns, both horizontally (diatopically) which include geographical variations and vertical (synoptic) which include variations in one place. This variation in a syntopic place can also penetrate into the study of social dialects involving social factors.

Furthermore, Kisyani also said that dialectology is a study of dialects somewhere. Dialect is a language variation that has its own lingual system that is used by certain groups of speakers; however, between these groups of speakers with 
other groups of speakers, it is still bound in one language. In general, dialectology refers to the study of geographical dialects, but actually the study of dialectology is not that narrow, in addition to learning about dialectological geography dialectology is also learning about social dialects. Social dialects are the study of dialects that involve variations in language and social factors in a place.

Ayatrohaedi (1983) emphasized that at the beginning, the notion of dialect referred to regional differences that existed in the observation areas which resulted in the mapping of languages / dialects / sub dialects. This understanding eventually also includes the social dimension. In dialectology, research that examines differences that exist in some observation areas (OA) is called a geographical dialect, while what happens as a result of differences in social dimensions is called a social dialect.

Sutardi (2007) stated that social dialect is determined by the foundation of social status / class, position / profession and the class of its speakers. On the other hand, the geographical dialect is based on the area or settlement of the speakers. Sutardi's opinion has clearly limited the difference between social dialect and geographic dialect. Social dialects are determined based on differences in society; these differences include the status / social class, position / profession and the class of the speakers. Whereas, the geographical dialect is determined based on differences in the region or the settlement of speakers.

In line with what Sutardi said, research on lexical differences and phonological differences of Javanese in Probolinggo, Surabaya, and Ngawi is a study that uses dialectology as its study. Javanese dialectological studies about geographic dialect studies with Probolinggo, Surabaya and Ngawi as research locations. Research subjects are adults. The study of geographic dialects is used to analyse the Javanese of adults in Probolinggo, Surabaya, and Ngawi.

\section{A. Lexical Differences}

Mahsun (1995: 54) stated that the scaled differences in the lexical term if the lexeme used to realize a meaning that is not derived from one language etymon. All lexical term differences are always variations. Mahsun stated that all lexical differences are always in the form of variations. For example, lexical differences in the Javanese language in Probolinggo, Surabaya, and Ngawi are the words "tomorrow," for example, in Surabaya tomorrow, it is said "mene" and in Probolinggo and Ngawi "tomorrow" it is said to be "sesok" These lexical differences will be described in this study so that it can be known a real picture of the differences between the Javanese in Probolinggo, Surabaya, and Ngawi.

Additionally, Nadra and Reniwati (2009: 28) stated that lexical differences or lexical variations are variations or differences in language found in the field of the lexicon. A difference is called a lexicon difference if the lexicon used to realize a meaning comes from a different etymon. In determining lexical differences, differences arising from the fields of phonology and morphology are considered non-existent. In other words, phonological and morphological differences are ignored in determining lexical differences.

According to Nadra and Reniwati, lexical differences are differences that exist in the lexicon in one language. In looking for lexical differences, ruled out phonological and morphological differences in one language. Javanese research in Probolinggo, Surabaya, and Ngawi analysed the lexical differences of Javanese by ruling out differences in phonology and morphological differences in Javanese.

\section{B. Phonological Differences}

Mahsun (1995: 24) stated that phonological variation is the differences found in lexeme which states the same meaning if the lexemes are derived from the same protolanguage. This phonological variation or difference means a new language formation (dialect) from the parent language, but not so much as to make a striking difference. The change is not drastic, but only a part of the "vowel" or "consonant" of the language.

Mahsun (1995: 34-38) stated that there are some sound changes that can be classified into changes in the form of variations, including a) assimilation is the process of changing one segment (sound) that resembles each other, b) dissimilation is a sound change so that the sound is different from what is nearby, c) metathesis that is the change of sound associated with the exchange of location between two sounds, d) the contraction is a change of sound that is related to the combination of two sounds into one sound, e) apheresis is sound obsolescence in the initial position, $\mathrm{f}$ ) syncope is a sound observer in the middle position, g) apokope is a sound observer in the final position, h) protesis is the addition of sounds in the initial position, i) epetensis is the addition of sounds in the middle position, and $\mathrm{j}$ ) paragraphs is the addition of sound in the final position.

The phonological differences in the Javanese in Probolinggo, Surabaya, and Ngawi will be analysed more deeply based on the forms of variation changes that have been conveyed by Mahsun (2005) both as assimilation, dissimilation, metathesis, contraction, aferesis, syncope, apocope, protesis, epetensis, and paragog. The phonological differences in the Javanese in East Java need to be investigated to find out the differences in Javanese in Probolinggo, Surabaya, and Ngawi.

\section{METHOD}

The current study is a quantitative study with descriptive methods. The data in this study were linguistic data that are adults' Javanese language in Probolinggo, Surabaya, and Ngawi. The research instrument was a questionnaire, a list of questions developed by Nothofer and modified by Kisyani by developing a swadesh list to be 829 glossaries of 
words/phrases. The observation areas (OA) were made at three locations, namely observation areas (OA) 1 and 2 are located in Probolinggo and the observation areas (OA) 3 and 4 are located in Surabaya. Meanwhile, the observation areas (OA) 5 and 6 are located in Ngawi.

The method used to collect the research data was the field observation method that is the researchers directly came to the field to search for research subjects, interview, hear, take notes, and record data. The field observation method is used by the researchers to observe linguistic data, geographical state, socio-cultural conditions, and the state of transportation infrastructure in the observation area. In addition, the researchers might also ask opinions and explanations directly to the subject of research about things that are poorly understood.

The data collection technique used by the researchers to collect adult Javanese language data in Probolinggo, Surabaya, and Ngawi was an advanced proficiency technique. The researchers and the research subjects met directly at the research location to have a direct conversation. The conversation is based on a list of questions that have been developed by Nothofer and modified by Kisyani by developing a Swadesh list into 829 glossaries of words/phrases. This advanced skill technique is always accompanied by note-taking techniques. The note technique was carried out by the researcher during the interview process with the research subject. The note-taking technique was carried out to avoid errors in phonetic writing. The data obtained in this note-taking technique would be matched with the data obtained from the recording. The data obtained from this note taking technique was used to complete the data contained in the recording. At the time of recording, the researcher tried his best so that the research subjects did not know this. This was done to maintain the nature of research data. To get the desired data, the researcher also used fishing techniques. This fishing technique might be carried out by movement or by certain words. Researchers lured the data out of the tool said the research subject.

The analysis was carried out through several steps: 1) data transcriptions, i.e. data obtained through recording were converted into written data. Data obtained through recording were changed according to their original phonetics. The data obtained from this recording technique were used as a complement to the data obtained through note-taking techniques using the Nothofer questionnaire modified by Kisyani by developing a swadesh list to 829 glossaries of words/phrases. 2) Data analysis; after the lexical and phonological differences in Javanese had been obtained, the observation areas that were possibly involved in communications were compared. The comparisons were carried out based on dialectometry triangles and a number of dialectometrics.

The following dialectometry formula is used

$(\underline{\mathrm{S} \times 100})=\mathrm{d} \%$

$\mathrm{n}$

Where $\mathrm{S}$ is the number of different from other observation areas, $\mathrm{n}$ is the number of maps to be compared, $\mathrm{d}$ is distance of vocabulary in percentages.

The results obtained will be used to determine the relationship between the observation areas with the following criteria:

1. Differences in lexical level

$81 \%$ and above: language differences

$51 \%-80 \%$ : dialect difference

$31 \%-50 \%$ : sub dialect difference

$21 \%-30 \%$ : speech difference

Below 20\%: no difference

2. Differences in phonological levels

$17 \%$ and above: language differences

$12 \%-16 \%$ : dialect difference

$8 \%-11 \%$ : sub dialect difference

4\% - 7\%: speech difference

$0 \%-3 \%$ : no difference

The following is a basic map of research locations that is taken from pffanon.wikia.com, a basic map of research sites: 


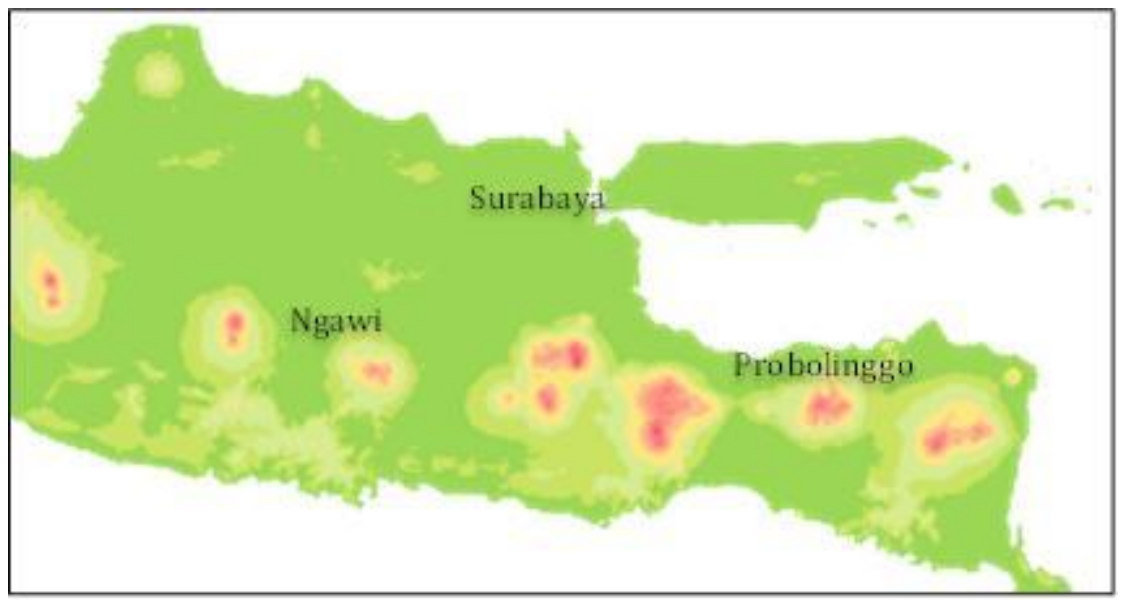

MAP 1: Research Location

At each research location, two observation areas (OA) were chosen that were the city and the suburb. Probolinggo City consists of two OAs as well as Surabaya, and Ngawi each consisting of two OAs. So the total number of OA in this study is six OA. The observation areas in Probolinggo, Surabaya, and Ngawi can be seen in map 2 as follows.

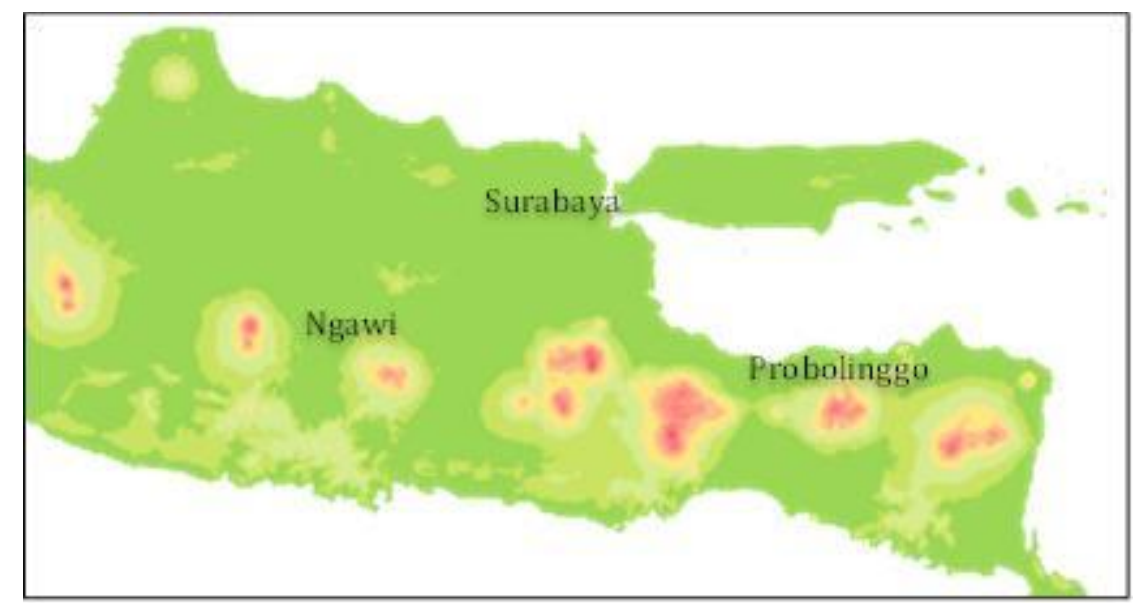

MAP 2: Observation Areas

Before calculating using the dialectometry method the mapping of the observation area is first carried out based on a triangular map and a lot of dialectometry. In the determination of triangles and a lot of dialectometry, there are several provisions that must be considered. The provisions are as follows:

1. The observation area (OA) which is comparable only to the observation area (OA) based on where each location may communicate.

2. Each observation area (OA) that may communicate directly is connected to a line so that a triangle with various shapes is obtained.

3. The lines of the dialectometry triangle should not intersect, it is better to choose one possibility that is closer to the other (Mahsun, 1995: 119).

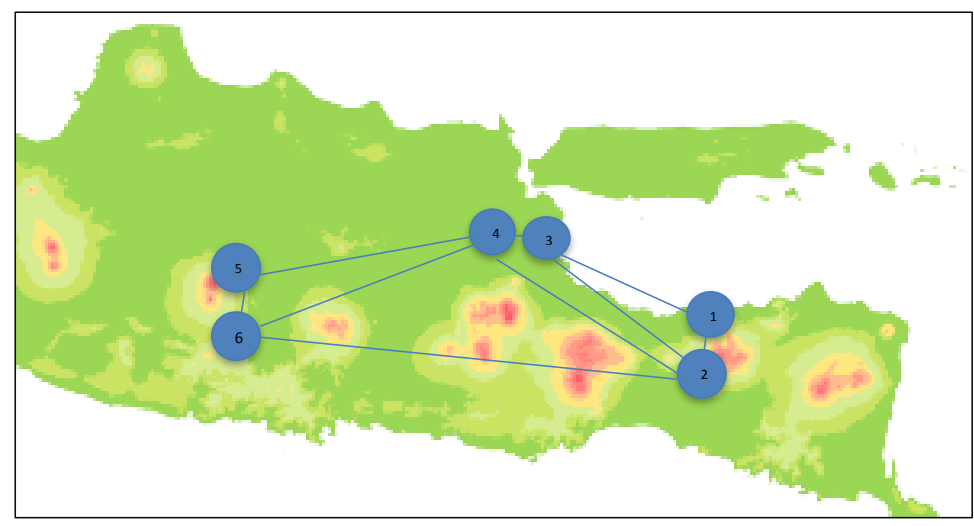

MAP 3: Dialectometry Triangle 
After making a dialectometric triangular map, a lot of dialectometry is made. Dialectometry multitude maps more visually to visualize the boundaries of OAs than dialectometry triangles because dialectometry triangles only connect with OAs, whereas a lot of dialectometry maps separate from OAs.

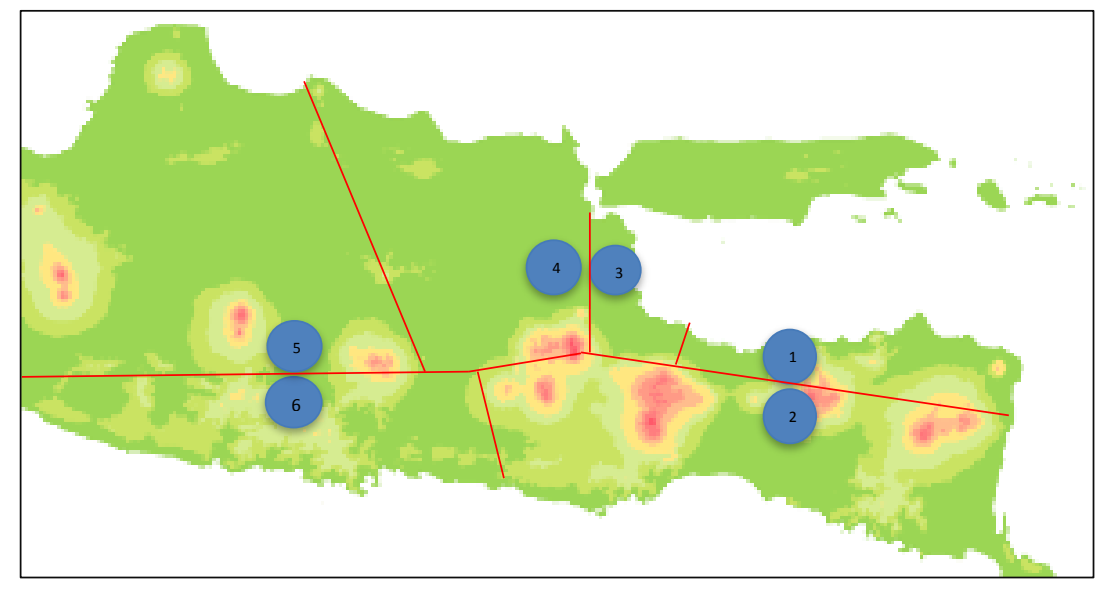

MAP 4: Polygon Dialectometry

Based on triangular maps and dialectometry maps, OA pairs were determined to decide lexical differences and phonological differences in the Javanese. The compared OA pairs can be seen in table 1 as below:

TABLE I

\begin{tabular}{lc} 
& $\begin{array}{c}\text { TABLE I } \\
\text { COMPARED OA }\end{array}$ \\
\hline No. & OA Pair \\
\hline 1. & $1-2$ \\
2. & $1-3$ \\
3. & $2-3$ \\
4. & $2-4$ \\
5. & $2-6$ \\
6. & $3-4$ \\
7. & $4-5$ \\
8. & $4-6$ \\
9. & $5-6$ \\
\hline
\end{tabular}

\section{DISCUSSION}

The lexical differences and phonological differences in Javanese in Probolinggo, Surabaya, and Ngawi were calculated based on lexical dialectometry and phonological dialectometry. The data retrieval of Javanese language in Probolinggo, Surabaya, and Ngawi was done using the Nothofer questionnaires which had been modified by Kisyani into 829 glossaries covering 20 meaning fields. The 20 meaning fields were: (1) numbers, (2) size, (3) season and time, (4) human body parts, (5) greetings and references, (6) kinship terms, (7) clothing and jewellery, (8) work, (9) animals, (10) animal body parts, (11) plants: parts of fruit and their processed products, (12) nature, (13) houses and their parts, (14) tools, (15) diseases and drugs, (16) directions, (17) activities, (18) nature, (19) colour and smell, and (20) taste.

\section{A. Calculation of the Number of Lexical Differences of Javanese}

The lexical data of Javanese in Probolinggo, Surabaya, and Ngawi shows that not all glossaries asked for the research subject were in Javanese ngoko. From 829 glossaries asked to adults in all observation areas, there were several glossaries answered using Indonesian. In addition, there was also zero or empty glossaries. The number of Javanese lexical at each observation area in Probolinggo, Surabaya, and Ngawi can be seen in table 2 as follows.

TABLE 2

THE NUMBER OF JAVANESE LEXICAL

\begin{tabular}{cccccc}
\hline \multirow{2}{*}{ No. } & Observation Area & \multicolumn{2}{c}{ Adults' Javanese Language } & Total \\
\cline { 3 - 5 } & & $\begin{array}{c}\text { Javanese } \\
\text { ngoko }\end{array}$ & Indonesian Language & \\
1. & 1 & 758 & 14 & Zero & 829 \\
2. & 2 & 757 & 23 & 49 & 829 \\
3. & 3 & 736 & 65 & 28 & 829 \\
4. & 4 & 732 & 69 & 28 & 829 \\
5. & 5 & 791 & 16 & 22 & 829 \\
6. & 6 & 791 & 16 & 22 & 829 \\
\hline
\end{tabular}


Based on the lexical calculation of Javanese language in Probolinggo, Surabaya, and Ngawi, the following groups were obtained:

a. OA 1; of the 829 glossaries that were asked there were 57 zero, 758 Javanese ngoko, 14 Indonesian.

b. OA 2; from 829 glossaries asked, there were 49 zeros, 757 Javanese ngoko, 23 Indonesian.

c. OA 3; from 829 glossaries asked, there were 28 zeros, 736 Javanese $n g o k o$ and 65 Indonesian.

d. OA 4; from 829 glossaries asked, there were 28 zeros, 732 Javanese ngoko and 69 Indonesian.

e. OA 5; from 829 asked, there were 22 glossaries, 791 Javanese ngoko and 16 Indonesian.

f. OA 6; from 829 asked, there were 22 glossaries, 791 Javanese ngoko and 16 Indonesian.

Based on the grouping, it can be seen that OA 3 and 4 located in Surabaya have fewer Javanese lexical than that in other OAs. The number of Javanese lexical at each OA in Probolinggo, Surabaya, and Ngawi can be seen in graph 1 as follows.

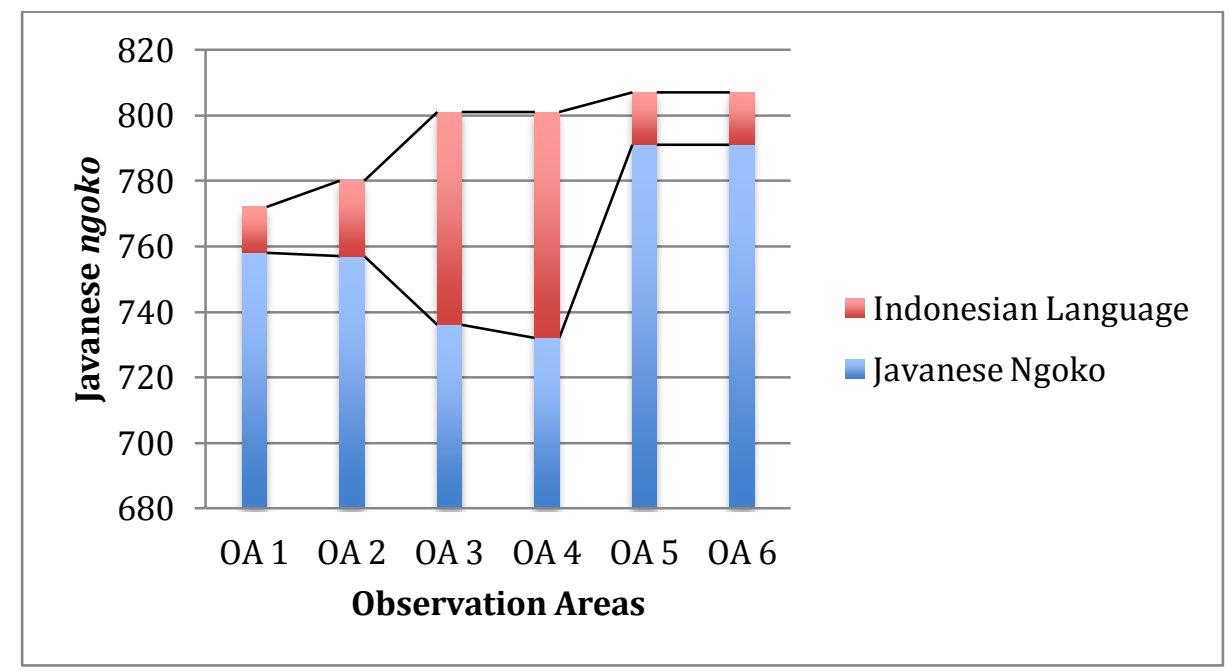

GRAPH 1: The Number of Javanese Lexical in Probolinggo, Surabaya, and Ngawi

The graph shows the number of lexical in each OA in East Java. The number of Javanese lexical in the west and east ends of East Java Province, namely in Probolinggo and Ngawi, was more than that in the centre of East Java Province, namely in Surabaya. Calculation of lexical differences in Javanese in Probolinggo, Surabaya, and Ngawi was done by referring to dialectometric triangular maps and numbers of dialectometry maps. However, the netted data show that not all OAs had Javanese language for the glossaries they were asking. For example: the CICIT kinship term (glossary no.210) with [buyut] was only known at OA 1,2,5, and 6 while in OA 3 and 4 it was unknown. This might be caused by being unproductive to use in everyday speech in OA 3 and 4. Of the 829 glossaries asked to adults at OAs 1, 2, 3, 4, 5, and 6 there were 349 lexical differences found. The results of calculating Javanese lexical dialectometry in Probolinggo, Surabaya, and Ngawi can be seen in table 3 as follows.

TABLE 3

\begin{tabular}{ccccc}
\multicolumn{5}{c}{ LEXICAL DialectOMETRY IN JAVANESE IN PROBOLiNGGO, SURABAYA, AND NGAWI } \\
\hline OA & $\begin{array}{c}\text { Number of } \\
\text { Difference } \\
(\mathrm{S})\end{array}$ & $\begin{array}{c}\text { Number of Maps } \\
\text { Compared } \\
(\mathrm{n})\end{array}$ & $\begin{array}{c}\text { Vocabulary } \\
\text { Distance } \\
(\mathrm{d} \%)\end{array}$ & $\begin{array}{c}\text { Description } \\
\end{array}$ \\
\hline $1-2$ & 112 & 349 & $32,09 \%$ & Sub-dialect differences \\
$1-3$ & 261 & 349 & $74,78 \%$ & dialect differences \\
$2-3$ & 187 & 349 & $53,58 \%$ & dialect differences \\
$2-4$ & 215 & 349 & $61,60 \%$ & dialect differences \\
$2-6$ & 151 & 349 & $43,26 \%$ & Sub-dialect differences \\
$3-4$ & 28 & 349 & $8,02 \%$ & no difference \\
$4-5$ & 187 & 349 & $53,58 \%$ & dialect differences \\
$4-6$ & 185 & 349 & $53,01 \%$ & dialect differences \\
$5-6$ & 48 & 349 & $13,75 \%$ & no difference \\
\hline
\end{tabular}

Based on the calculation of the lexical dialectometry of Javanese ngoko language in Probolinggo, Surabaya, and Ngawi, the following division groups were obtained:

a. OA which shows no difference or vocabulary distance with a percentage of $0 \%-20 \%$ were found in OA 3-4 and OA 5-6.

b. OA which shows speech differences with a percentage of $21 \%-30 \%$ were not found.

c. OA which shows the differences in the sub dialect with the percentage of 31\%-50\% was in OA 1-2, and OA is 2-6.

d. OA which shows the difference in dialect with the percentage of 51\%-80\% was found in OA 1-3, OA 2-3, OA 2-4, OA 4-5, and OA 4-6. 
Calculation of lexical differences in Javanese in Probolinggo, Surabaya, and Ngawi shows no difference in OA 3-4 and OA 5-6. Sub dialect differences were found in OA 1-2 and OA 2-6. Differences in dialects were found in OA 1-3, OA 2-3, OA 2-4, OA 4-5, and OA 4-6. The differences in Javanese language and sub dialects in Probolinggo, Surabaya, and Ngawi can be seen in map 5 as below.

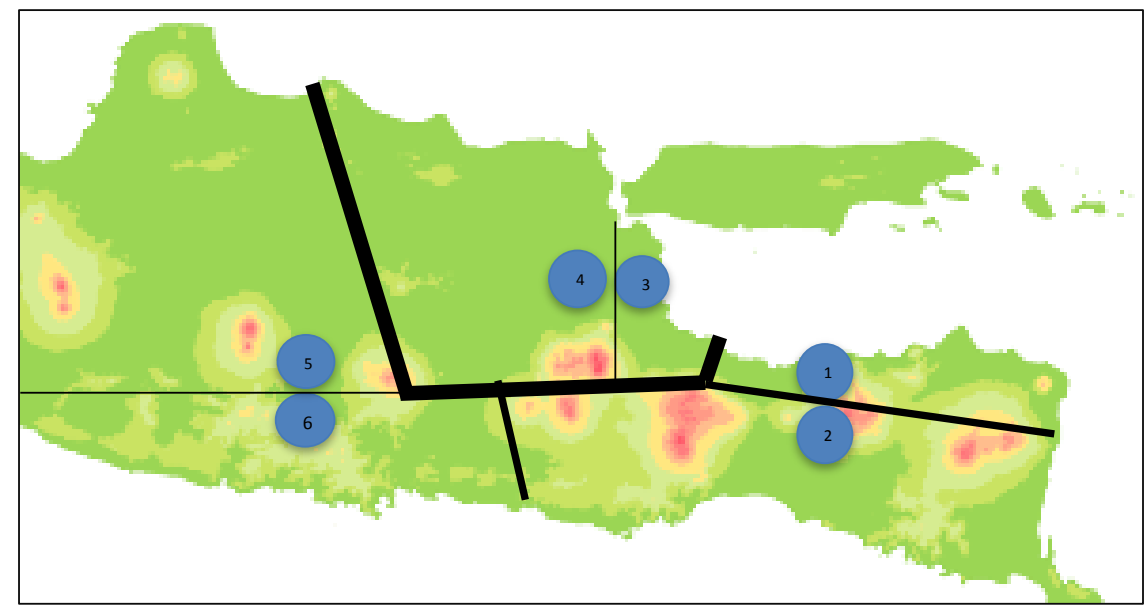

MAP 5: A Map of Lexical Differences in Javanese in Probolinggo, Surabaya, and Ngawi

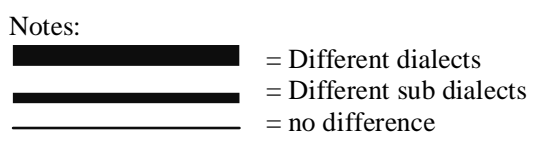

\section{B. Calculation of the Number of Phonological Differences of Javanese}

Calculation of phonological differences in Javanese in Probolinggo, Surabaya, and Ngawi shows variants and correspondence. Of the 829 glossaries asked to adults at OA 1, 2, 3, 4, 5, and 6 there were 272 phonological differences found. The number of the phonological differences was the number to calculate the phonological dialectometry of Javanese in Probolinggo, Surabaya, and Ngawi. This number might develop if other differences that contain the same thing were involved. The phonological calculation of Javanese language in Probolinggo, Surabaya, and Ngawi can be seen in table 4 as follows.

TABLE 4

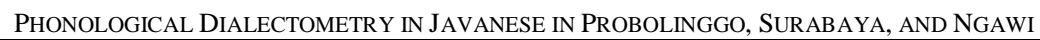

\begin{tabular}{|c|c|c|c|c|}
\hline $\mathrm{OA}$ & $\begin{array}{l}\text { Number of } \\
\text { Difference } \\
\text { (S) }\end{array}$ & $\begin{array}{c}\text { Number of Maps } \\
\text { Compared } \\
(\mathrm{n})\end{array}$ & $\begin{array}{c}\text { Vocabulary } \\
\text { Distance } \\
(\mathrm{d} \%) \\
\end{array}$ & Description \\
\hline $1-2$ & 11 & 272 & $4,04 \%$ & speech differences \\
\hline $1-3$ & 17 & 272 & $6,25 \%$ & speech differences \\
\hline $2-3$ & 11 & 272 & $4,04 \%$ & speech differences \\
\hline $2-4$ & 15 & 272 & $5,51 \%$ & speech differences \\
\hline $2-6$ & 13 & 272 & $4,77 \%$ & speech differences \\
\hline $3-4$ & 5 & 272 & $1,83 \%$ & no difference \\
\hline $4-5$ & 14 & 272 & $5,14 \%$ & speech differences \\
\hline $4-6$ & 17 & 272 & $6,25 \%$ & speech differences \\
\hline $5-6$ & 8 & 272 & $2,94 \%$ & no difference \\
\hline
\end{tabular}

Based on the calculation of phonological dialectometry, Javanese language in Probolinggo, Surabaya, and Ngawi is grouped into the following groups division:

a. OA which shows no difference or vocabulary distance with a percentage of $0 \%-3 \%$ were found in OA $3-4$ and OA 5-6.

b. OA which shows the difference of speech with the percentage of $4 \%-7 \%$ was in OA 1--2, OA 1 - 3, OA 2 - 3, OA 2 - 4, OA 2 - 6, OA 4 - 5, and OA 4 - 6.

c. OA which shows sub dialect differences with a percentage of $8 \%-11 \%$ were not found.

d. OA which shows dialect differences with a percentage of $12 \%-16 \%$ were not found.

The calculation of the phonological differences shows speech differences in OA 1--2, OA 1-3, OA 2-3, OA 2-4, OA 2-6, OA 4-5, and OA 4-6. This proves that there were many phonological similarities between Javanese languages between OAs. The phonological differences in Javanese language in Probolinggo, Surabaya, and Ngawi can be seen in graph 2 as follows. 


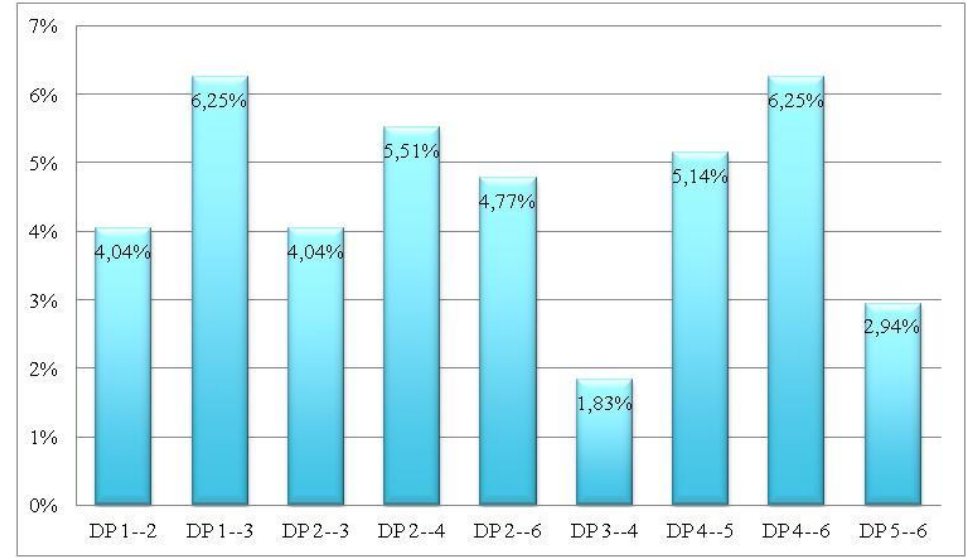

GRAPH 2: The Percentage of Phonological Differences in Javanese in Probolinggo, Surabaya, and Ngawi

Phonological differences in OA 1--2, OA 1-3, OA 2-3, OA 2-4, OA 2-6, OA 4-5, and OA 4-6 indicated that there were speech differences while those in OA 3-4 and OA 5-6 showed no speech difference. The map of the phonological differences in Javanese language in Probolinggo, Surabaya, and Ngawi can be seen in map 6 which shows the difference in speech in the OA-OA compared.

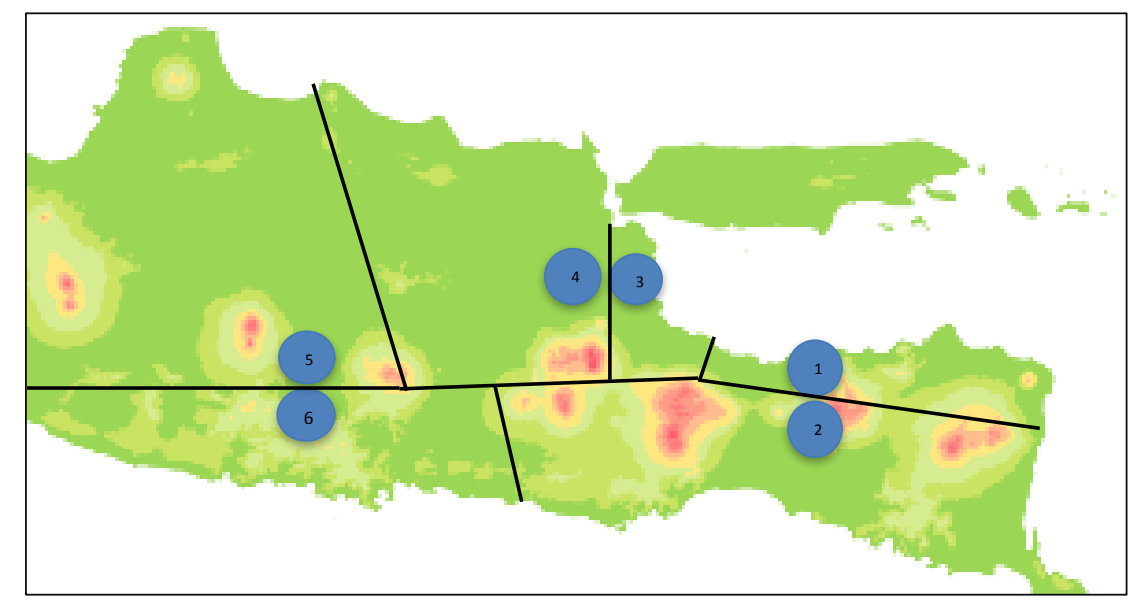

MAP 6: A Map of Phonological Differences in Javanese in Probolinggo, Surabaya, and Ngawi Notes:

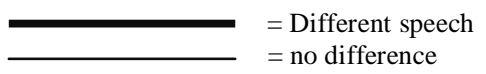

The map of Javanese phonological differences above showed thickening in OA 1--2, OA 1-3, OA 2-3, OA 2-4, OA 2-6, OA 4-5, and OA 4-6 which indicated the different lines of speech. OA 3-4 and OA 5-6 did not indicate any thickening because there was no difference in the OA-OA compared.

\section{CONCLUSION}

The conclusions from the results of the study on lexical differences and phonological differences in Javanese language in Probolinggo, Surabaya, and Ngawi are: 1) the most lexical of Javanese is in the western and eastern parts of East Java, while the least is in the centre of East Java Province, i.e. Surabaya, 2) lexical differences in Javanese in Probolinggo, Surabaya, and Ngawi produced one dialects and two sub-dialects and 3) phonological differences in Javanese in Probolinggo, Surabaya, and Ngawi produced three utterance.

\section{ACKNOWLEDGEMENTS}

This paper is funded by Directorate of Research and Public Service, Directorate General of Research and Development Enforcement, Ministry of Research, Technology, and Higher Education, Indonesia.

\section{REFERENCES}

[1] Adipitoyo, Sugeng. (2011). Morfofonemik Bahasa Jawa. Surabaya: Citra Wacana.

[2] Aliana, Zainul arifin. (2003). Bahasa Daerah: Beberapa Topik. Inderalaya: Universitas Sriwijaya.

[3] Aslinda and Leni Syafyahya. (2007). Kedwibahasaan, Dwibahasawan, dan Diglosia. Bandung: Refika Aditama. 
[4] Ayatrohaedi. (1983). Dialektologi: Sebuah Pengantar. Jakarta: Pusat Pembinaan dan Pengembangan Bahasa, Depdikbud.

[5] Chambers, J. K, dkk. (ed.) (2002). The Handbook of Language Variation and Change. USA: Blackwell Publishing.

[6] Chambers, J. K dan Peter Trudgill. (1990). Dialektologi. Terjemahan Annuar Ayub. Kuala Lumpur: Dewan Bahasa dan Pustaka.

[7] Erawati, Ni Ketut Ratna. (2017). The Relativity Strategy of Old Javanese. Journal of Language Teaching and Research 8.6, 1100-1108. http://dx.doi.org/10.17507/jltr.0806.10.

[8] Ferguson. C. A. (1959). "Diglossia" dalam Anwars. Dill. Editor 1971. Language Structure and Language Use. Standford. California: Standford University Press.

[9] Grosjean, Francois. (1982). Life with Two Languages. Cambridge: Harvard University Press.

[10] Hadiati, Chusni. (2017). The Realization of Intensifiers in Banyumas Dialect. Journal of Language Teaching and Research 8.5, 940-947. http://dx.doi.org/10.17507/jltr.0805.14.

[11] Ika Mamik Rahayu. (2018). Variasi Dialek Bahasa Jawa di Wilayah Kabupaten Ngawi: Kajian Dialektologi. Retrieved August 16, 2005 from https://www.semanticscholar.org/author/Ika-Mamik-Rahayu/70317700.

[12] Kartikasari, E., Laksono, K., Savitri, A., \& Suryarini, D. (2018). A Study of Dialectology on Javanese "Ngoko" in Banyuwangi, Magetan, and Solo. Humaniora 30.2, 128-139. http://doi.org/1022146/jh.29131.

[13] Kisyani-Laksono. (2004). Bahasa Jawa di Jawa Timur Bagian Utara dan Blambangan (Kajian Dialektologis). Jakarta: Pusat Bahasa Departemen Pendidikan Nasional.

[14] Kisyani-Laksono dan Agusniar. (2009). Dialektologi. Surabaya: Unesa University Press.

[15] Lauder, Multamia Retno Mayekti Tawangsih. (1993). Pemetaan dan Distribusi Bahasa-Bahasa di Tangerang. Jakarta: Pusat Pembinaan dan Pengembangan Bahasa.

[16] Mahsun. (1995). Dialektologi Diakronis. Yogyakarta: Gadjah Mada University Press.

[17] Mahsum. (2005). Metode Penelitian Bahasa. Yogyakarta: Grasindo Jaya.

[18] Meillet, Antoine. (1970). The Comparative Method in Historical Linguistics. Trans. Gordon B. Ford. Paris: Libraire Honore Champion.

[19] Meillet, Antoine. (1970). The Reconstruction of Proto-Malayo-Javanic.S-Gravenhage: Martinus Nijhoff.

[20] Patricia, Eze. (2019). Dialectal Variation: A Critical Study of Umunze Igbo. Journal of Language and Linguictics 6.2, 51-66. https://jolledu.com.ng/index.php/joll/article/view/105

[21] Petyt, K. M. (1980). The Study of Dialect: An Introduction to Dialectology. London: Andre Deutsch.

[22] Poerwadarminta. (1953). Sarining Paramasastra Djawa. Djakarta: Noordhof Kolff NV.

[23] Poedjosoedarmo, Supomo. (1979). Tingkat Tutur Masyarakat Jawa. Widya Parwa 22 Yogyakarta: Balai Penelitian Bahasa Yogyakarta.

[24] Purwaningsih, Apriani. (2017). Geografi Dialek Bahasa Jawa Pesisiran di Desa Paciran Kabupaten Lamongan. International Conference on Art, Language, and Culture Proceeding. 4 November 2017. ISBN 9786025057601.

[25] Romaine, Suzane. (1989). Bilingualism. New York: Basil Blackwell Ltd.

[26] Sasangka, Sry Satriya Tjatur Wisnu. (2011). Paramasastra Gagrag Anyar Basa Jawa. Jakarta: Yayasan Paramalingua.

[27] Sudaryanto. (1992). Metode dan Teknik Pengumpulan Data. Yogyakarta : Gajah Mada Unipress.

[28] Suhono, Antun. (1953). Reringkesaning Paramasastra Jawa. Yogyakarta: Hien Hoo Sing.

[29] Sumarsono. (1993). Metode dan Aneka Teknik Analisis Bahasa: Pengantar Penelitian Wahana Kebudayaan secara Linguistik. Yogyakarta: Duta Wacana University Press.

[30] Sutardi, Tedi. (2007). Mengungkap keberagaman Budaya. Bahasa, dialek, dan tradisi lisan. Bandung: PT. Setia Purna Inves.

[31] Weinreich, Uriel. (1968). Language in Contact. The Hague: Mouton Publishers.

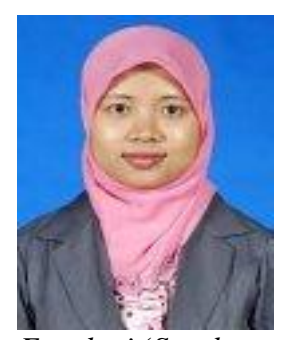

Erlin Kartikasari was born in Magetan, East Java, Indonesia on September 20th 1987. She received her Master degree in Javanese and Indonesian Language and Literature Education from Universitas Negeri Surabaya, Indonesia in 2013.

She is currently a Lecturer in Faculty of Language and Science, Universitas Wijaya Kusuma Surabaya, Indonesia. Her research interest includes linguistics, especially dialectology of Javanese languages. Some scientific articles are already published on national journals and international journal, namely; A Study of Dialectology on Javanese "Ngoko" in Banyuwangi, Magetan, and Solo, The Lexical And Phonological Differences Of Javanese In Banyuwangi And Surabaya, Perkembangan Peta Isolek Bahasa Jawa di Surabaya dan Magetan Tahun 2013 dan Tahun 2018, Kajian Dialektologi: Perbedaan Leksikal dan Perbedaan Fonologi (Surabaya, Indonesia: UWKSPress, 2018).

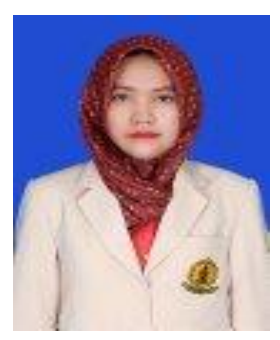

Diyas Age Larasati was born in Mojokerto, East Java, Indonesia on 9th October 1989. She majored in geography education Faculty of social science in 2012. Then, she continued her studies and got her Master degree in Geography education from Malang State University, Indonesia in 2014.

She is currently a Lecturer in Faculty of Language and Science, Universitas Wijaya Kusuma Surabaya, Indonesia. Her research interest includes education and social science especially geography education. Scientific articles are already published on accredited national journals, namely; Pengaruh model Problem Based Learning terhadap kemampuan pemecahan masalah geografi SMA, Pengaruh model Treffingger terhadap kemampuan berpikir kreatif mahasiswa PGSD Universitas Wijaya Kusuma Surabaya, ect. 


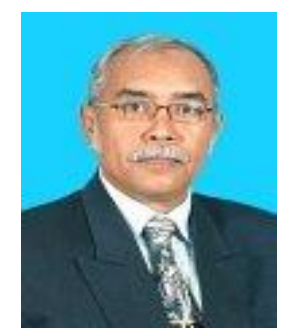

Wakit A. Rais, was born in Ngawi, East Java, Indonesia on April, 01, 1960. He received his Professor of ethnolinguistic from Universitas Sebelas Maret.

He is currently a Vice Dean of General and Financial Affairs, Faculty of Humanities. His research focuses on ethnolonguistic. Scientific articles are already published on national journals and international journal, namely; Javanese Languages and Culture in the Expression of Kebo Bule in Surakarta: An Ethnolinguistic Study, Kearifan Lokal dalam Bahasa dn Budaya Jawa: Studi Kasus Masyarakat elayan di Pesisir Selatan Kebumen (Kajian Etnolinguistik), Local Wisdom Summarized in the Javanese Proverb: A Case Study of the Javanese Community in ExResidency on Surakarta (An Ethnolinguistic Study), etc.

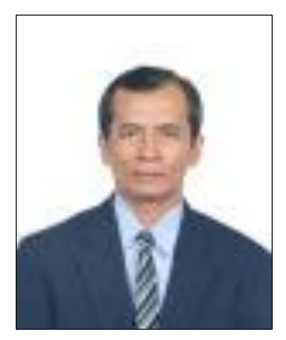

Warto was born in Karanganyar, East Java, Indonesia on September, 25, 1961. He received his Professor of History from Universitas Sebelas Maret.

He is currently a Dean of Faculty of Humanities. His research focuses on history. Scientific articles are already published on national journals and international journal, namely; Tantangan Penulisan Sejarah Lokal, Revitalisasi Kesenian Kethek Ogleng untuk Mendukung Pengembangan Pariwisata di Kabupaten Wonogiri. Wayang Beber Pacitan: Fungsi, Makna, dan Usaha Revitalisasi. The Social Banditry in the Rural Areas of Rembang by the End of the $19^{\text {th }}$ Century and at the Beginning of the $20^{\text {th }}$ Century. Hutan Jati Berkalung Besi: Pengangkutan Kayu Jati di Jawa Pada Akhir Abad ke-19 dan Awal Abad ke-20, etc. 